\title{
O NOVO PAPEL DO ENFERMEIRO
}

" $A$ resolução que se processa nos países desenvolvidos, após a era da tecnologia, é a da informática"' sāo assertivas de que estamos tomando conhecimento. Enquanto isto, no mundo todo, praticamente, se aceleram mu danças sociais. Os direitos do homem vão ficando mais claros para as diferentes etnias de toda a terra. A saúde é requisito dos mais essenciais à vida.

O III Plano Nacional de Deservolvimento 1980/85, quanto a nosso setor, estabelece inicialmente: " $A$ orientação básica é a de ampliar e melhorar os serviços de saúde pública, intensificando o combate às endemias e fortalecendo as atividades relacionadas com a medicina preventiva. Paralelamente, far-se-á vasto esforço para reduzir os custos"....

Maior número, gradualmente, de enfermeiros e de demais pessoal de enfermagem deverá ser absorvido pelos programas de interiorização das ações de saúde e saneamento, os quais se expandem, aos poucos, no País.

A partir do Plano Decenal de Saúde para as Américas, deve haver assis‘ência primária cada vez mais. Tal assistência foi assim definidas por peritos da Organização Pan-Americana de Saúde/OMS (1976): "E o conjunto de açöes pouco complexas, mas efetivas, que se põe à disposição do indivíduro, familia e comunidade para promover e conservar a saúde, assim como para repará-la e prevenir a doença. Usualmente é o meio através do qual se facilita o acesso do usuário a níveis de assistência mais complexos e custosos."

Este tempo atual é o de mudança do papel do enfermeiro. No interior do Brasil, ao balcão da farmácia (no qual não está, de regra, o farmacêutico, mas sim uma pessoa prática) e aos tratamentos caseiros acorrem as camadas mais numerosas dos habitantes. $O$ enfermeiro é o profissional de saúde pos sivelmente mais adequado para a assistência primária. E escasso. Sua distribuiçăo pelos serviços de saúde é de grande interesse para que se cumpram os programas do setor. 
O enfermeiro deverá, daqui por diante, ser graduado de ta! modo que fique receptivo às idéias novas, democráticas, de saúde para todos. E toda uma geração de brasileiros a procurar caminhos novos, soluções novas. Cremos que todos nós compreenderemos ter ohegado o tempo de se nos tornarmos úteis a nosso país e a nossa gente. (H.G.D.) 